\title{
The Determinants of Public Education Expenditures: An Empirical Analysis of Changing Patterns and Growth of Public Expenditure on Education in Kenya
}

\author{
David Kamar Imana \\ PhD Candidate at Graduate School of Public Administration (GSPA), \\ National Institute of Development Administration (NIDA), Bangkok, Thailand. \\ E-mail: imanadavid@gmail.com
}

Received: August 10, 2017 Accepted: August 28, 2017 Online published: October 9, 2017 doi:10.5296/jpag.v7i4.11972

URL: https://doi.org/10.5296/jpag.v7i4.11972

\begin{abstract}
This paper examined several factors that affect growth of public expenditure on education sector using reputable theories of public policy analysis, economics, and public finance. These theories were used to test and examine these factors mainly for the purposes of providing public policy recommendations. Standard multiple linear regression analysis method was used to analyze factors affecting growth of public expenditure on education using the four formulated models and equations representing; general education sector, primary, secondary and university education. The results in general showed that majority of the factors tested were positively significant and caused an increase of public expenditure on education. The paper found noticeably increase in public expenditure on education sector in Kenya since 1980 from the results, but still the actual amount of money spend on education sector is less than what is required. Therefore, the government should not only increase financial allocation but should also find reliable sources of funding education sector. In addition, the government should carry out reviews in all schools syllabuses in order to meet current changing jobs demands and maintaining quality education.
\end{abstract}

Keywords: Determinants, public education, expenditure, empirical analysis, changing patterns, Kenya

\section{Introduction}

Public spending is an instrument of economic growth which is used to stimulate the economy, build human capital, or provide welfare services for all. The universal access to basic 
education has increased in an attempt by the government of Kenya to support National Educational Goals, International Conventions on education and UNESCO instruments by supporting fully free primary and free day Secondary Education, (Ndonga, 2017). A country that invests heavily in education development is anticipated to benefit from a number of things ceteris paribus. The country will not only realize general economic growth but also get ample skilled and trained manpower. Other scholars are in agreement with this statement and in addition, they argue that a country will also witness low crime rates, high life expectancy, national peace and political stability (Abuya et al, 2013; Ojiambo, 2009; Amutabi, 2003).

The government of Kenya efforts in supporting education is visible as it strives hard to provide quality, equitable and affordable education for all. In the recent past, the poor households have immensely benefited from basic education policies of free primary and free day secondary education (Imana, 2017). In order to improve the quality and accessibility in the education, the government needs not only allocating more financial resources but should also put proper rules and financial management frameworks. Jerono (2009) argued that Kenya has seen remarkable vicissitudes across all key sectors since independence in 1963 in terms of the size, policies and distribution of government expenditure. Kenya GDP per capita was 1,376.71 USD in 2015 (WB, 2015) while gross domestic product is 63.4 billion USD (WB, 2015). The Kenyan economy grew by 4.6 per cent in 2012 to 5.7 per cent in 2013 and in 2014 the economy dropped to 5.3 per cent and late increased to 5.6 per cent 2015.

\subsection{Trend of Public Expenditure and Enrolments}

The education sector had the highest expenditure amongst the key sectors in the republic of Kenya. This indicates that education sector is one of the few sectors that received the highest allocation throughout the 35 years under this study. Defence and Agriculture sector received more allocation in between 1980 to 1990 while transport received the highest allocation from 2006 to 2014 as seen in Figure 1. In 2014, total public expenditure was Kshs. 1,925 billion in 2014. The public expenditure for education sector was Kshs.3,21 billion in 1980 which increased to Kshs.339.09 billion in 2014. Education sector had a huge expenditure during introduction of free primary and free day secondary education in 2003 and 2008 respectively. The total education expenditure had 19.7 per cent increase in the 2003 when total expenditure was Kshs.76.72 billion compared to the previous year whereby the expenditure was Kshs.64.11 billion. On other hand, free day secondary education increased from Kshs.121.78 billion in 2007 to Kshs. 138.25 billion in the year 2008 which was 13.5 per cent increase.

The enactment of free primary education has largely increased the number of enrolments across all levels of education. Primary level enrolments increased from 3.9 million pupils in the year 1980 to 13 million pupil in the 2014. An outstanding increase of 8.6 million pupils in the year 2003 was witness during introduction of free primary education. This made the sector to have an average enrolment of 10.7 million pupils from the year 2003 to 2014. At secondary level enrolment increased from 400 thousand pupils in 1980 to 2.3 million pupils in 2014 while the university enrolment was steady from 1980 to 2000 before increasing sharply from 2000 to 2014 and total enrolment was 29,469 and 631,795 in 1980 and 2014 respectively. 


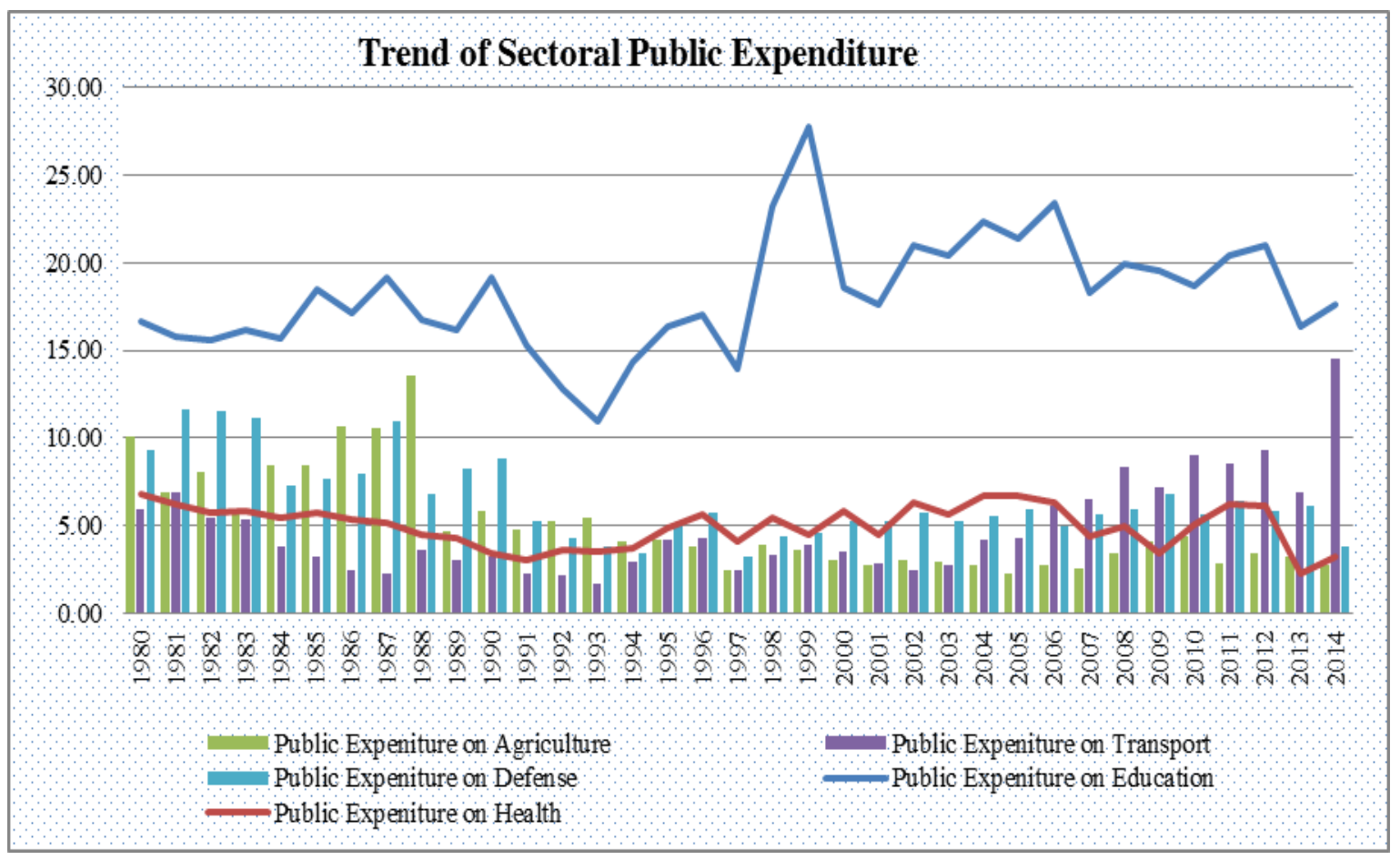

Source of Data: Republic of Kenya, MOEST, MOFNT and Kenya Economic Surveys from 1985 - 2016.

Figure 1. Trend of public expenditure in key sectors, 1980 - 2014

\subsection{Education System in Kenya}

The current education system (8-4-4 system) was started by His Excellence President Daniel Toritich Arap Moi, the second president of the republic of Kenya in 1985. The education system was designed to improve and address problems related with academic education such as reducing the scarcity of technical skills. This was supported by the government when at first it introduced vocational subjects in both primary and secondary education levels which were under "the umbrella" of 8-4-4-system syllabus (Mwiria, 2002). The 8-4-4-system comprises of eight years in primary, four years in secondary, and four years university education (See Figure 2). The Kenya National Examination council (KNEC) is mandate to prepare, set, mark and administer national exams countrywide for both primary and secondary education. A primary pupil seats for his/her Kenya Certificate of Primary Education (KCPE) after eight years of studies while secondary student seats for his/her Kenya Certificate of Secondary Education (KCSE) after completing 4 years of studies. The middle level colleges in Kenya one takes 2-3 years to complete while it takes 1-2 years to finish village/youth polytechnic. The arrows shown in Figure 2, shows direct formal link one follows in the 8-4-4 system while dotted arrows show an indirect link implying that it is not a must for one to follow. 

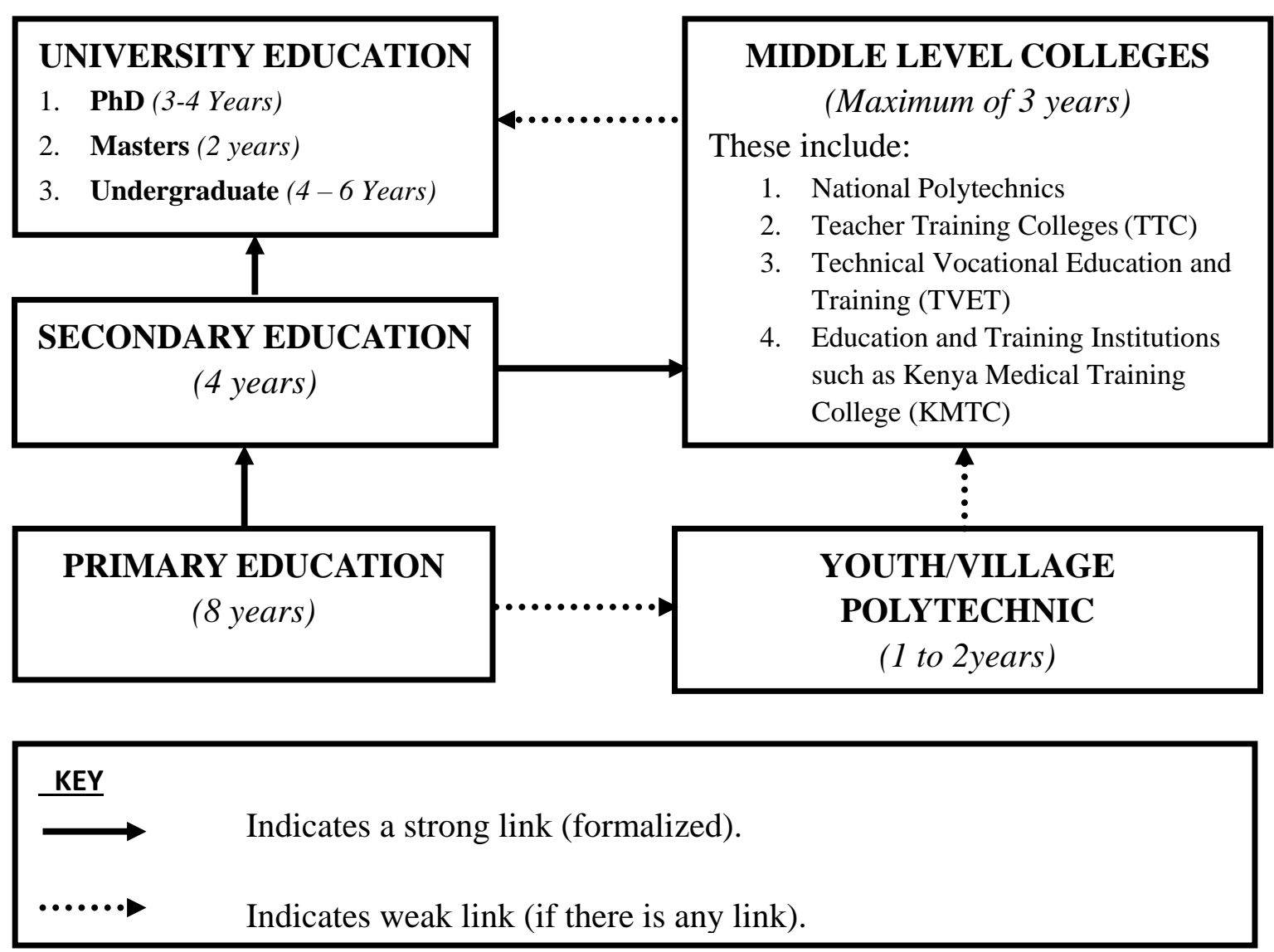

Figure 2. Structure of Education Sector in Kenya

\subsection{Problem Statement}

Kenya has greatly invested in education yet this is not acquiescent proportionately to outcomes since there is poor access to education facilities by majority of Kenyans living in rural and cities' slums. It is very sad five decades since independence; many regions still experience lack of basic education facilities such as classes and reading materials. The low quality of education as seen from these neglected regions has made a number of stakeholders in the education sector to ask questions concerning the relevance of the current education system, funding criterion used and quality of education across all levels. According to Imana (2016), rapid growth of public expenditure on education, increase in enrolments, and policy implementation challenges are three main problems affecting education sector in Kenya. In Kenya, funding and cost of education remains a big problem especially in higher education levels and yet public expenditure on education keeps on growing. Bwonda (2013) argued that there exist a bigger percentage of children not yet enrolled to the education system due to vast and uncountable problems affecting their parents despite the recent witnessed high increase of enrolments in Kenya. In the education sector, there has been conflict between quality and quantity of education. This is the reason why the ever increasing enrolment trends in education is not marching facilities which were initially intended for few students (Malechwanzi et al, 2016). In addition, the recent poor education indicators and vast 
variations in the outputs across the country are not matching with government education objectives and goals, Bwonda (2013). Therefore, this paper tries to find trends and factors affecting growth of public expenditure on the education sector.

\subsection{Objective and Contribution of the Paper}

The main objective of this paper was to examine recents trends on public expenditure, enrolments and deeply analyzing various factors that affect the growth of public expenditure on education sector in Kenya from the year 1980 to 2014. Assessments of the growth of public expenditure on education can assistance the government in formulating an inclusive fiscal policy framework. This paper, therefore, makes the contribution to the literature of education policy and education expenditures in Kenya across all levels of education. It also supports and contributes to the financial theoretical assumptions that support the increase of public expenditure especially in the African context. Further and future research at the country level will be motivated by the results of this study since it explains in details various expenditure theories, why education expenditure keeps on increasing and which level receives more financial allocations.

\section{Literature Review}

\subsection{General Overview}

In the recent past, expenditure and economic literature has surrounded itself on the distinguished theories of public policy, economics, and of finance origin. Majority of past researches are in agreement that public sector expenditure impacts positively on economic growth. Example of notable theories were provided by Keynes (1936), Wagner (1893), Peacock and Wiseman (1961). Government expenditure on public sector keeps on increasing every financial year not only because of economic growth but it is also triggered by the political and electorate demands in the country (Imana, 2016). Government expenditure on various sectors sometimes grows at faster rate than the revenue the government collects and is in agreement with Economic-Demographic Theory explanation that citizen always put pressure on governments as the demand better services. Politicians are forced to come up with policies to address the demands created in the outside environment other than in the political system. These outside demands comprises of population increases and the ability of citizens to pay taxes to the government. The scenario and explanation has been explained and echoed by number researches (Imana, 2016; Mzonde, 2013; Lindert, 2009:3; Al-Samarrai, 2003; Musgrave and Musgrave, 1989; Levit and Joyce 1987; Dye, 1978). According to Tanzi and Schuknecht (2000), an increase in literacy rates supports by larger margins good quality of life in the long run and this is because of an increase in public expenditure and expansion of government role in education sector despite the international education funding and increase in public education financial allocation. There are various problems still facing education sector in Kenya for example; high dropout rates, low primary-secondary transition rate and lack of sustainable funding mechanisms (Imana, 2016; Muhamad, 2011).

Worldwide, the education experts and stakeholders have argued severally in different forums that government financial resource allocation is largely dependent upon political and social 
conditions which are currently not matching with economic dynamics and prevalence. The standards and quality of education despite the fast growing public spending on the education sector is being questioned by all education stakeholders in Kenya (Imana, 2016). Deolalikar (1998) argued that Kenya is allocating more budgets to education sector in comparison with other countries in Sub-Saharan Africa although Deolalikar did not give detailed explanation. This is the sole reason to why the government's funds education sectors so as to improve education standards and quality, reduce poverty and inequality gap, and make education accessible to all.

\subsection{Theoretical Explanation}

This paper used public policy, economics and finance theories to explain on factors that affect growth of public expenditure on education in Kenya. The specific arguments were based on; economic-demographic,incrementalism, political business cycle, compensation, and fiscal illusion theories. A number of researchers have used these theories in different studies and results differs from country to country maybe because some studies used a few variables or theoiries in trying to explain and justify their findings. Therefore, this paper explains each theory in details especially on how it causes increase of public expenditure in relation to Kenya's education sector.

\subsubsection{Compensation Theory}

This theory explains the impact of globalization on the international trade and financial flows between countries and government policy on public expenditure. The size of the welfare expenditure such as education can largely be affected by globalization undertakings either directly or indirecctly (Mzonde, 2013; Yoon, 2009). The compensaion theory asserts that an increase in external trade leads to a stiff competition in the countries involved in free trade agreements and the end result is that weak domestic companies suffer in the form of reduced sales and this may cause enormous losses. The decrease in sales volumes and enormous losses by these companies is caused by an increase of imported cheap commodities which at the end leads to price decrease, complications in foreign exchange market, reduction of exports, unemployment and even their closure. The government has one option of intervening through provision of compensation especially to those who lost their jobs as a result of trade liberalization and these forces the government to increase its budget (Yoon, 2009; Ventura, 2006; and Rodrick, 1998).

\subsubsection{Economic-Demographic Theory}

This theory claims that public expenditure in many cases increases more than the normal collected revenue that supports it. The office-bearers in a particular country are confronted with pressure and demands from the general public. Sometimes these demands might not be easy to control and they include; population growth, urbanization related issues, basic service demands, and tax remittance ability by the citizens (Mzonde, 2013; Dye, 1978; Musgrave, 1989). As a result of population increase, the number of pupils and students joining various education levels will also increase. The end results is that government will be forced to increase financial allocation to the education sector to cater for high enrolments and therefore 
increasing education expenditure as well. There are a number of factors related to Economic-Demographic Theory and in this study, the following factors were used; inflation, Real GDP per capita, population growth, enrolments across all educational levels, and urbanization. The assumption made was that these factors have a positive effect on the growth of public expenditure on education.

\subsubsection{Quantity Theory of Money}

This theory states that the overall price level of goods and services is directly proportional to the amount of money in circulation (Milton, 2010). The upsurge in money supply is mirrored by an equal increase in nominal output, or gross domestic product whereby an increased money supply causes reduction in interest rates and further spending and therefore an increase aggregate demand (Fisher, 1911; Foville, 1907 and Newcomb, 1885). Normally, aggregate demand is the total sum of consumer and government expenditure, investment and net exports. This means that an increase of money supply leads to an increase in consumer spending and therefore, public expenditure increases as well.

\subsubsection{Fiscal Illusion Theory}

Fiscal illusion concept has been proposed by many public choice scholars such as Buchanan and Wagner (1977) and Wallace E. Oates (1989). The premise is that the tax system design could lead to underestimation of the costs of public expenditure, with the public not fully informed of taxation total costs. According Niskanen (2004), Fiscal illusion also can be seen in deficit spending, he found out that there exists a strong negatively relationship between the relative of government spending and tax revenues collected. Niskanen explanation was that tax reduction and deficit spending causes the cost of government look as if it is cheaper than it or else would be. The burden of indirect taxes would also be systematically undervalued by means of fiscal instruments (Puviani, 1903; Mill, 1848).

According to Fiscal Illusion Theory, politicians respond to the demands of voters that put them into office in different ways under different conditions. The politicians tend to wow voters by increasing public expenditure in response to the demand of the low-income voters who through ballot demand equality in the country by voting politicians who are likely to respond to their demand. This means that for the part in power to remain in the next election, politicians come up with good policies to benefit the voters for the sake of re-election (Dye, 2005; Lindert, 2004; Musgrave and Musgrave, 1989). This study also clarified how foreign aid or grants affects the increase of public expenditure, according to McGillivray and Morrissey (2001), aid or grant illusion is a condition whereby a country misperceives the actual value of the grant inflow, or the expenditure situations attached to the inflow. The explanation given was that aid illusion occurs in an environment of imperfect information and weak public expenditure management. Therefore, the increase of foreign grants increases government's revenue which in turns entices the government to increase expenditure.

\subsubsection{Incremental/Growth Theory}

Public expenditure can also be influenced by using routine government methods of budgeting whereby the current public spending can be obtained by a marginal or incremental increase 
from what was spent last year as in argument provided by the Incremental Theory (Charles E. L., 1959). According to this theory, public expenditures increase since it is based on past trends of the expenditure. This means that in order to make a new budget, one need to refer to the previous budget allocation and only a narrow range of increases or decreases is considered for the next budget (Dye, 1978). The policymakers have limited information of citizen's needs and are not responsive to the demands of the environment. This explains the reason as to why policymakers tend to use last year's expenditure as their base and only slightly adjust the present one from that of the last year.

\subsubsection{Political Business Cycle Theory}

This theory expounds why the the government in power always tends to spend more during the electioneering period and limit the spending almost to normal levels after elections. This implies that public expenditure, fiscal deficit, and money supply increase in the year before and the year of the elections, and these factors contract after the elections, forcing public expenditures up and down respectively. The following scholars and researchers have tried to give the explanation of this theory (Block, 1999; Allen et al. 1986; Heckelman and Whaples 1996; Synder, Jr., and Yackovlev, 2003). The election cycle was taken into account to test the political business cycle in the country. A number of researches such as Potrafke (2006) have indeed used the election cycle factor to explain the effects of election to the country's expenditure especially on education sector. Therefore, as Kenya is a democratic country, and elections are being conducted after every 5 years, in this study it was necessary test the effects of elections on educational expenditure.

\section{Research Methodology}

The quantitative approach was used to collect the data from Kenya in order to carry out research on the factors affecting the growth of public expenditures on education. The standard multiple regression analysis method was used to evaluate factors affecting growth of public expenditure on education sector. This method was designed to analyze the content and character of education expenditure especially the enrolment trend and growth of public expenditure on education. The quantitative method basically uses a random sampling and structured data collection approaches that are suitable for the planned responses. In addition, this method encompasses testing of models and hypotheses derived from theories in order to conduct evaluation of the size of a phenomenon of interest in this case growth and impact of public expenditure on the education sector.

\subsection{Data Collection}

The use of secondary data for this kind of research was crucial since the data was previously collected by credible and reliable institutions such as government agencies and international organizations such as World Bank and International Monetary Fund. It is debated that collection of secondary data by individual scholars might not be credible and reliable particularly when it comes to government data on expenditures and budget. Boslaugh (2007) expounded that secondary data analysis usually contains analysis of data collected by someone else. According to Vartanian (2010), other than the initial purpose of the collected 
secondary data, this data can be used to answer other research questions. The desk research was carried out where consolidated data was not available so as to extract data from various documents. The secondary data collected for this study covered expenditure on various education levels, for example; primary, secondary and university levels from the past 35 years (1980 to 2014). In summary, the data was obtained from various domestic and international institutions, domestically it was collected from; the Ministry of Education, Science and Technology, Ministry of Finance, Kenya National Bureau of Statistics, Ministry of Devolution and National Planning, Central Bank of Kenya, and other government agencies such as higher education board (HELB) and commission of university education (CUE). The study also collected data from previous studies, surveys reports, and international organizations such as International Monitary Fund and World Bank.

\subsection{Data and Unit of Analysis}

The descriptive research design was adopted for this part which was ex-post facto in nature. The population of the study comprised the population of all public schools in Kenya in all levels of education. The main rationale of selecting the three levels of education was to determine the level of education and region (rural or urban) that had the highest public expenditure funding in Kenya during the period under study $(1980-2014)$. The examination included the tests for outliers, tests for normality, linearity, and homoscedasticity, tests for Multicollinearity and amongst other techniques. The descriptive tools for this study included the use of diagrams, tables, figures and percentages while the analytical tool used the contemporary co-integration test in the analysis of data. This was realized using Standard Multiple Linear Regression Analysis Method using SPSS (21) software that was used to determine factors that affect the growth of public expenditure on the education sector.

\subsection{Models Used}

The study used public expenditure as main dependent variable which was further subdivided into four variables, namely; education spending as a percentage of total government expenditure (GE), primary education spending as a percentage of government expenditure (GP), secondary education spending as a percentage of government expenditure (GS), and university education spending as a percentage of government expenditure (GU). In relation to the results obtained as well as the availability of variables, the models below were developed representing each level of education in carrying out the investigations about growth of public expenditure on education. Therefore, testing each education subsector or level separately was important since it was possible to know the impact of income distribution well. In order to test the impact of these policies the equations below were formulated to represent subsectors or levels of education.

\footnotetext{
(i) $\quad \mathbf{G E}=\mathrm{a}+\mathrm{b}_{1} \mathrm{INF}+\mathrm{b}_{2} \mathrm{PCG}+\mathrm{b}_{3} \mathrm{URB}+\mathrm{b}_{4} \mathrm{DEF}+\mathrm{b}_{5} \mathrm{ITR}+\mathrm{b}_{6} \mathrm{GEt}-1+\mathrm{b}_{7} \mathrm{PTEM}+\mathrm{b}_{8} \mathrm{STEM}+\mathrm{b}_{9} \mathrm{DUEL}+\mathrm{b}_{10} \mathrm{GLOB}$

+ b11GRANT + b 12 TGE

(Model-1)

(ii) $\mathbf{G P}=\mathrm{a}+\mathrm{b} 1 \mathrm{INF}+\mathrm{b} 2 \mathrm{PCG}+\mathrm{b}_{3} \mathrm{URB}+\mathrm{b} 4 \mathrm{DEF}+\mathrm{b}_{5} \mathrm{ITR}+\mathrm{b}_{6} \mathrm{GEt}-1+\mathrm{b} 7 \mathrm{PTEM}+\mathrm{b}_{8} \mathrm{DUEL}+\mathrm{b} 9 \mathrm{GLOB}$ $+b_{10}$ GRANT $+b_{11}$ TGE

(Model-2)

(iii) $\quad$ GS $=a+b_{1} I N F+b_{2}$ DEF + b3ITR $+b_{4}$ GLOB + b5GSEN $+b_{6}$ DEBT $+b_{7}$ MS - b8AGRI

(Model-3)

(iv) $\mathbf{G U}=\mathrm{a}+\mathrm{b}_{1}$ PCG $+\mathrm{b}_{2} \mathrm{URB}+\mathrm{b}_{3}$ GUEN $+\mathrm{b}_{4} \mathrm{GE}_{\mathrm{t}-1}+\mathrm{b}_{5}$ DEBT $+\mathrm{b}_{6}$ GLOB $+\mathrm{b}_{7}$ GRANT $+\mathrm{b}_{8}$ DUE (Model-4)
} 


\section{Whereby:}

GE, GP, GS, GU stand for public expenditure on overall education; primary, secondary and University levels; PCG = Real GDP per capital growth; URB = urbanization; INF = inflation rate; GRANT = foreign grant received by government; DUEL $=$ holding of general elections; DUPE $=$ free primary education; $\mathrm{GE}_{\mathrm{t}-1}=\mathrm{one}$ year lagged public expenditure on education; GLOB = globalization; DEF = fiscal deficit; ITR = indirect tax revenue; GPEN = primary school gross enrolments; GSEN = Secondary School gross enrolment; GUEN = university gross Enrolment; PTEM = Primary teachers employment; STEM = Secondary teachers employment; AGRI = public expenditure on agriculture; TGE = total public expenditure; DEBT = public domestic debt; MS $=$ money supply $(\mathrm{M} 2)$ growth.

$\mathbf{a}=$ constant, and $\mathbf{b}_{1}$ to $\mathbf{b}_{12}=$ Coefficients of each independent variable with dependent variable .

\subsection{Conceptual Framework}

The study used various theories' factors as shown in the conceptual framework (see Figure 3) to determine changes in the size of public expenditure with the intent of testing their effects on education provision in Kenya.

\section{Economic-Demographic Factors}

- $\quad$ Inflation (+)

- $\quad$ Real GDP per capita (+)

- $\quad$ Population growth $(+)$

- Students' enrolments $(+)$

- Urbanization growth (+)

- Teachers' employment (+)
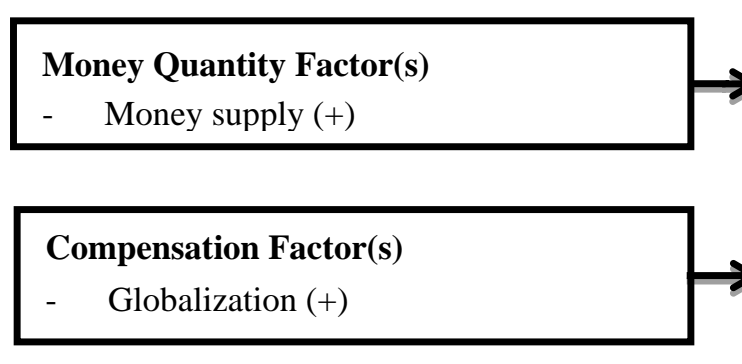

\section{Incremental Factor(s)}

- $\quad$ Lagged Expenditure (+)

\section{Political Factor(s)}

- Election (+)

\section{Growth of Public Expenditure}

1. Education sector expenditure

2. Education expenditure by level

2.1 Primary expenditure

2.2 Secondary expenditure

2.3 University expenditure

\section{Fiscal Illusion Factors}

- Grants (+)

- Increase in fiscal deficit (+)

- $\quad$ Indirect tax revenues (+)

Figure 3. Multi-Dimensional Analysis of Factors Affecting Public Expenditure 


\section{Note:}

All factors are discussed in theories explanation part and Multiple Regression Analysis Method was used to test these factors. Also, all independent variables were assumed to have positive effect on dependent variables.

Just as reported in a number of studies, some factors increase public expenditure while others reduce and this depends upon varied circumstances although the initial assumption was that all factors have a positive effect on public expenditure on education. According to Davoodi et al. (2003:8), and Selowsky (1979:4), if government services are provided to individuals, they should be used in the analysis. This study investigated effects of factors (see Figure 3) that affect changes in public expenditure on education, that is public expenditure on; primary, secondary and University levels. According to Snyder, Jr., and Yackovlev (2000:19), expenditure of various education levels should be assessed independently.

\section{Results and Discussion}

\subsection{Results}

The main objective of this study was to analyze factors that effects growth of public expenditure on education in Kenya in an attempt to give explanation to why government expenditures keep on increasing. Therefore, four models were formulated and tested. It was found that there was mix results in comparison to the initial theories' prediction and hypotheses formulated. The formulated models were tested using regression, as found, some of factors made the public expenditure to increase which was either in agreement with hypotheses formulated or disagreeing with them. What was clear is that effects of factors influencing education expenditure were not uniform in each education sub-sector, for example, inflation was significant in both primary and secondary sub-sectors but not in general education sector and university level. In order to bring to the clear picture on factors that increase or decrease the growth of public expenditure on education is explained next.

\subsection{Education Sector (Model-1)}

The introduction of free primary and free day secondary education has shown Kenya's commitment to providing basic education to all. This can be seen through huge budget allocation to primary and secondary education. Model-1 in this study represents general education sector and various factors were used in the equation. In order to evaluate and analyze the contributions made by each independent variable (factors) to the increase of public education expenditure, observation of the regression coefficients results was used. Model-1 variables were run and yielding R2 of .815, Adjusted R2 of .714 with an F-value of 8.072, showing that model-1 contributes about 71.40 per cent growth to the general public expenditure growth on the education sector.

A number of factors as used in Model-1 were by good margin significant meaning they affected the growth of public education expenditure positively. This is well explained by unstandardized beta coefficient figures (see Appendix A1), for example, the following factors were positively significant; Real GDP per capita $(\mathrm{PCG}=.062)$, budget deficits $(\mathrm{DEF}=.030)$, 
education lagged expenditure (GEt-1=.001), secondary teachers employment (STEM=.032), and total public expenditure (TGE=.007). On the other hand, the following factors were negatively significant; primary teachers employment (PTEM=.095), dummy election figures (DUEL=.042), and education monetary aid (GRANT= .053). Initially, the study made an assumption that all independent variables will have positive effects on the growth of public expenditure on education as provided by the theories used but after testing Model-1, some of the independent variables had negative effects for example; PTEM, DUEL and GRANT. The equations below, shows Mode-1 before and after testing.

\section{Before Testing Model-1}

(a) $\mathbf{G E}=\mathrm{a}+\mathrm{b}_{1} \mathrm{INF}+\mathrm{b}_{2} \mathrm{PCG}+\mathrm{b}_{3} \mathrm{URB}+\mathrm{b}_{4} \mathrm{DEF}+\mathrm{b}_{5} \mathrm{ITR}+\mathrm{b}_{6} \mathrm{GE}_{\mathrm{t}-1}+\mathrm{b}_{7} \mathrm{PTEM}+\mathrm{b}_{8} \mathrm{STEM}+\mathrm{b}_{9} \mathrm{DUEL}+\mathrm{b}_{9} \mathrm{GLOB}+$ $\mathrm{b}_{10} \mathrm{GRANT}+\mathrm{b}_{11} \mathrm{TGE}$

After Testing Model-1

(b) $\mathbf{G E}=-\mathrm{a}+\mathrm{b} 1 \mathrm{INF}+\mathrm{b} 2 \mathrm{PCG}+\mathrm{b} 3 \mathrm{URB}+\mathrm{b} 4 \mathrm{DEF}+\mathrm{b} 5 \mathrm{ITR}+\mathrm{b} 6 \mathrm{GEt}-1-\mathrm{b} 7 \mathrm{PTEM}+\mathrm{b} 8 \mathrm{STEM}-\mathrm{b} 9 \mathrm{DUEL}+\mathrm{b} 9 \mathrm{GLOB}$ - b10GRANT+b11TGE

The government of Kenya place has made primary and secondary education a priority especially during allocation of the budget. The total increase in general public expenditure (TGE) and lagged budget $\left(\mathrm{GE}_{\mathrm{t}-1}\right)$ were significant and positive leading to an increase in public expenditure on education. The government of Kenya had to allocate more financial resources to education sector to support free primary and free day secondary education in its attempt to provide basic education to all. The employment of more secondary teachers (STEM) after commencing of free day secondary in 2008 led to significant growth of public education expenditure since the new teachers were paid. The increase in budget deficit (DEF) cause a significant increase in public expenditure on education and this shows that an increase in government borrowing automatically causes an increase in revenue which again entices the government to even spend more. The real per capita income (PCG) on the other hand was significant with general public expenditure on education as well.

\subsection{Primary Education (Model-2)}

The government of Kenya introduced free primary education for all in 2003. Therefore, Model-2 was need to test and examine the effects of the factors on public expenditure on the primary level using Standard Multiple Linear Regression Analysis. The result obtained significantly explains 92.20 percent of the change in public expenditure on education, with Durbin-Watson of 1.810 and F-change of 37.562. This means that Model-2 contributes immensely to the growth of public expenditure on primary education in Kenya and therefore, the null hypothesis was rejected. It worth noting that three factors were positively significant in Model-2 and they included; inflation, Primary teachers employment, and total government expenditure. In Model-2, five factors caused significant changes in public expenditure on primary education reflecting Kenya's government efforts and commitment in providing basic education to all. 
The introduction of free primary education led to the employment of more primary teachers (PTEM), increase in total government expenditure (TGE), and an increase of inflation (INF) with a positive effect of 35.70 per cent, 21.20 per cent and 18.60 per cent respectively ceteris paribus (see Appendix A2). On the other hand, two factors, urbanization (URB) and budget deficit (DEF) negatively reduced public expenditure on primary education. It is worth noting that there were other factors that had positive effects on public expenditure on education in Model-2 though they were not significant and these factors included; budget increment which contributed 9.8 percent, per capita growth which contributed 8.6 percent, elections years effect (dummy figures) which contributed 6.8 percent, and lastly, increase of foreign aid (GRANT) which contributed 1.6 percent (see Appendix A2). These factors require the government to pay more attention especially in coming up with education policies that will promote equity and quality. The government through the ministry of education, science, and technology needs to come up with well-defined funding frameworks and plan to meet ever increasing free primary expenditure. The equations below, shows Mode- 2 equation before and after testing.

\section{Before Testing Model-2}

(a) $\mathbf{G P}=\mathrm{a}+\mathrm{b} 1 \mathrm{INF}+\mathrm{b} 2 \mathrm{PCG}+\mathrm{b} 3 \mathrm{URB}+\mathrm{b} 4 \mathrm{DEF}+\mathrm{b} 5 \mathrm{ITR}+\mathrm{b} 6 \mathrm{GEt}-1+\mathrm{b} 7 \mathrm{PTEM}+$ b8DUE+b9GLOB+b10GRANT +b11TGE

After Testing Model-2

(b) $\mathbf{G P}=-\mathrm{a}+\mathrm{b}_{1} \mathrm{INF}+\mathrm{b}_{2} \mathrm{PCG}-\mathrm{b}_{3} \mathrm{URB}-\mathrm{b}_{4} \mathrm{DEF}-\mathrm{b}_{5} \mathrm{ITR}+\mathrm{b}_{6} \mathrm{GE}_{\mathrm{t}-1}+\mathrm{b}_{7} \mathrm{PTEM}+\mathrm{b} 8 \mathrm{DUEL}+\mathrm{b}_{9} \mathrm{GLOB}+$ $b_{10}$ GRANT + $b_{11}$ TGE

Inflation (INF) in general has become education' nemesis since to forces the parents and government to spend more on school fees and other necessary school requirements. This is because during inflation, the prices of essential goods such as; textbooks, uniforms, sleeping mattresses for boarding schools, pens and shoes just to name but a few have doubled or even trippled. The government employment of new primary teachers to cater for ever increasing enrolments in primary schools has forced the government to allocate more funds in order to pay teachers. This is the reason why employment of primary teachers (PTEM) increased public expenditure on primay education. The total education expenditure (TGE) was positively significant meaning it caused expenditure on primary education to increase. The reason behind it is that during the introduction of free primary education the government had to allocate more financial resources to this program and therefore, expenditures increased. On the hand, urbanization (URB) was negatively significant because many unemployed young professionals relocated to the urban centers which results to an increase of costs of living in the due to high population. This has caused basic amenities such as food, water, health, housing and transport expensive.

\subsection{Secondary Education (Model-3)}

In this model, factors that affect public expenditure on secondary education were tested using 
Standard Multiple Linear Regression Analysis. The results showed that the model explains 75.20 per cent of the variance of public expenditure on secondary education and F-change of 13.881. Secondary education is the most vital level of education in Kenya since it is at this juncture that students join tertiary levels of education or go to employment sector directly. The introduction of free and day secondary education program introduced in 2008 was commissioned towards meeting the needs of both the students who intend to complete at secondary school level and those who intend to proceed to an advanced level. In this context, the secondary school curriculum gives emphasis to job-tailored courses such as technical education, business, and information technology skills. In a nutshell, secondary education is meant to prepare students to positively contribute to the country's development and on top of that be self-reliant, supportive, self-discipline, and always be patriotic in matters related to national interests (Sifuna, 1990).In Model-3, only inflation (INF) was positively significant meaning it increased public expenditure on secondary level while money supply was negatively significant indicating that it caused decrease in public expenditure.

In summary, four factors were found to be causing the upward growth of public expenditure on secondary education and they were; inflation, secondary enrolment (GSEN), agriculture expenditure (AGRI) and domestic debt (DEBT) with the positive effect of 43.4 per cent, 34 per cent, 17.3 per cent and 1 per cent in that order. On the other hand, three factors namely; budget deficit (DEF), interest rates (ITR) and lastly, globalization (GLOB) affected the growth of public expenditure negatively though they were not significant (see Appendix B1). Again, these factors require immediate government intervention. High inflation (INF) causes prices of commodities and services to become expensive and this will make parents to be unable to meet high school fees and costs of school required items such as uniform and books. The government intervenes by allocating more funds to secondary education to meet the high cost of living to enable every citizen to benefit. The public expenditure in most cases is stimulated by more money supply (MS) in the market which again causes inflation, supply of more money entices the consumers to spend more which in the long-run causes the prices of essential commodities and services to increase. The demand for commodities will reduce and consumers will be having less to spend since the prices will be more. Therefore, parents taking their children to school will find it hard to pay school fees and buying essential school materials such as books. The equations below, shows Mode- 3 before and after testing.

\section{Before Testing Model-3}

(a) $\mathbf{G S}=\mathrm{a}+\mathrm{b}_{1} \mathrm{INF}+\mathrm{b}_{2} \mathrm{DEF}+\mathrm{b}_{3} \mathrm{ITR}+\mathrm{b}_{4} \mathrm{GLOB}+\mathrm{b}_{5} \mathrm{GSEN}+\mathrm{b}_{6} \mathrm{DEBT}+\mathrm{b}_{7} \mathrm{MS}+\mathrm{b}_{8} \mathrm{AGRI}$

After Testing Model-3

(b) $\mathbf{G S}=\mathrm{a}+\mathrm{b}_{1} \mathrm{INF}-\mathrm{b}_{2} \mathrm{DEF}-\mathrm{b}_{3} \mathrm{ITR}-\mathrm{b}_{4} \mathrm{GLOB}+\mathrm{b}_{5} \mathrm{GSEN}+\mathrm{b}_{6} \mathrm{DEBT}-\mathrm{b}_{7} \mathrm{MS}+\mathrm{b}_{8} \mathrm{AGRI}$

The reason why secondary expenditure is not appealing is because the government does not pay whole school expenses instead parents dig deeper into their pockets in order to take their children go to school. In addition, the government of Kenya does not give secondary education more priority like primary education. The introduction of day secondary education program in 2008 has not produced desired results since more than half all schools in Kenya 
are boarding schools. The government needs to improve in its budget allocation and management of secondary education.

\subsection{University Education (Model-4)}

University education in Kenya receives subsidies and funding inform of student loans, bursaries and scholarships. The result in Model-4 shows that only one factor was positively significant (PCG) and four factors had positive effects though not significant, namely; university enrollment (GUEN), incremental budget ( $\left.\mathrm{GE}_{\mathrm{t}-1}\right)$, general election (DUEL) and foreign aid contributing (GRANT). This mean that during allocation of financial resources to university level, the decision makers based their resolutions regarding whether to increase the budget or not on the above mentioned factors that had positive effects. As a result, real per capita income growth, university enrollment, lagged budget, general election and foreign aids are the major factors influencing the growth of public expenditure on the university education. Model-4 yielded an adjusted R2 value of .295, with an F-statistic of 1.361. This means that the model explains 29.50 percent growth in public expenditure on university education in Kenya. On the other hand, three factors in Model-4, namely; urbanization (URB), globalization (GLOB) and domestic debt (DEBT) had negative effects on public education expenditure therefore; they led to the reduction of expenditure on education (see Appendix B2) conflicting with the model assumption and prediction.

The trend of real per capita (PCG) expenditure for education sector in developing countries has been increasing in the past few years (Danuvas, 2012). The increase in real per capital leads to improvements in social indicators which include increase in education spending that not only supports fairness but it also quickens individuals' general developments. Increase in the real per capita income in the long-run leads to the development of citizens' living standards and also increases their call for better public services. When resources of a particular population increase, the population is not only able to pay more taxes to the government directly or indirectly but they also able to pay for their children's school fees. The Economic-Demographic Theory concept comes to play in both in the increase in per capita income and education policy implementation. Conventionally, many countries or states favor using the previous financial year budgets to determine the current financial year budgets; they use incremental approach $\left(\mathrm{GE}_{\mathrm{t}-1}\right)$ approach (Dye, 1978; Etzioni, 1967:387; Lindblom, 1959:84). In Model-4, lagged or incremental budget showed positive effects on public university expenditure and since Kenya is a democratic country, politicians usually avoid long confrontation and debating by adapting this method in most cases. Politicians in trying to avoid time wastage, and long process of agreeing on what is appropriate in terms of budget in parliament, the resort in going quick by passing the budget. This is one of the reasons why public expenditure keeps on growing each year. The effect of grants at the university level was positive although not significant and it led to the rise of public expenditure on university education. When grants are directed to education sector, public expenditure on education rises significantly (Mzonde, 2013; Stasavage, 2005:352). As seen in this study, grants have not been targeted directly to the education sector but a number of tertiary institutions have benefited indirectly from government development programs. The equations below, shows Mode-4 before and after testing; 
Before Testing Model-4

(a) $\mathbf{G U}=\mathrm{a}+\mathrm{b}_{1} \mathrm{PCG}+\mathrm{b}_{2} \mathrm{URB}+\mathrm{b}_{3}$ GUEN $+\mathrm{b}_{4} \mathrm{GE}_{\mathrm{t}-1}+\mathrm{b}_{5}$ DEBT $+\mathrm{b}_{6}$ GLOB $+\mathrm{b}_{7}$ GRANT $+\mathrm{b}_{8}$ DUEL After Testing Model-4

(b) $\mathbf{G U}=\mathrm{a}+\mathrm{b}_{1} \mathrm{PCG}-\mathrm{b}_{2} \mathrm{URB}+\mathrm{b}_{3} \mathrm{GUEN}+\mathrm{b}_{4} \mathrm{GE}_{\mathrm{t}-1}-\mathrm{b}_{5}$ DEBT $-\mathrm{b}_{6} \mathrm{GLOB}+\mathrm{b}_{7}$ GRANT $+\mathrm{b}_{8}$ DUEL

\section{Conclusion and Recommendation}

\subsection{Conclusion}

The results of the four models tested representing all education sub-sectors, namely; general education sector (model-1), primary subsector (model-2), secondary subsector (model-3) and lastly, university sub-sector (model-4) is displayed in Table 1 below. The major Theories assumption was that all factors will have positive effect on the growth of public expenditure on education. Table 1, shows summary of initially expected theory effects and the four model results after conducting the test on factors assumed to cause growth of public expenditure on education sub-sectors.

Table 1. Expected Theory Effects and Models Results

\begin{tabular}{lccccc}
\hline \multirow{2}{*}{$\begin{array}{l}\text { Independent } \\
\text { Variable }\end{array}$} & $\begin{array}{c}\text { Expected } \\
\text { Theory Effect }\end{array}$ & $\begin{array}{c}\text { Model-1 } \\
\text { Results }\end{array}$ & $\begin{array}{c}\text { Model-2 } \\
\text { Results }\end{array}$ & $\begin{array}{c}\text { Model-3 } \\
\text { Results }\end{array}$ & $\begin{array}{c}\text { Model-4 } \\
\text { Results }\end{array}$ \\
\cline { 2 - 6 } PTEM & + & - & + & $*$ & $*$ \\
GLOB & + & + & - & - & - \\
GSEN & + & $*$ & $*$ & + & $*$ \\
GUEN & + & $*$ & $*$ & $*$ & + \\
PCG & + & + & + & $*$ & + \\
URB & + & + & - & $*$ & - \\
AGRI & + & $*$ & $*$ & + & $*$ \\
DEBT & + & $*$ & $*$ & + & - \\
DEF & + & + & - & - & $*$ \\
DUEL & + & - & + & $*$ & + \\
GEt-1 & + & + & + & $*$ & + \\
GRANT & + & - & + & $*$ & + \\
INF & + & + & + & + & $*$ \\
ITR & + & + & - & - & $*$ \\
MS & + & $*$ & $*$ & - & $*$ \\
TGE & + & + & + & $*$ & $*$ \\
\hline
\end{tabular}

Note:

1. (+) Means agreement with the theory and (-) Means contradiction with the theory.

2. (*) Means not included in the model.

The outcome of this paper displays different and mix results since some factors had positive or negative effects on public expenditure on education. The government needs to pay more attention to the factors that are positive but not significant so as to meticulously know the 
trends of public expenditure on education as explained at the start of this paper giving results of each model representing dependent variables. In summary, a good number of factors identified for this study had a positive effect on public expenditure on education sector (Model-1) in comparison with other sub-sectors.

Kenya public expenditure on education is determined mainly by the political will of the leading majority and party in power. Just as witnessed in Kenya's 2017 election campaigns, Imana (2017) argued that provision of subsidized education in Kenya has been a major political campaign tool for political parties to gain fame or be voted in. There are a number of factors that significantly affect public expenditure on education sector and sub-sectors in this study. Free primary and free day secondary education policies' implementation in 2003 and 2008 respectively to some extend led to the growth of public expenditure on education as a whole. The government of Kenya since the adoption of free primary education in 2003 has continuously supported this policy through the allocation of more financial resources to this education sub-sectors. In support of this, Kenya has witnessed not only the increase of financial resources to education but also seen the increase in; schools' enrollments, new schools, and employment of teachers around the country. The increase of enrolments in schools is in agreement with Economic-Demographic Theory which says that increase of enrolments forces the government to increase financial allocations to Ministry of Education, Science and Technology in order to enable children not only pay for their fees but also expand studying facilities.

The ruling government is responsible in deciding priorities, expected government education model, and understanding of the current economic and political stage. In the previous year's government choices and judgments have pertinently influence public expenditure on education sector as whole simply because of inertia and incrementalism allocation practice. This suggests that the public expenditure on education is completely in the hand of political decision-makers without essentially reliance on the economic setting. This explains birth of both free primary and free day secondary education in Kenya which was introduced in 2003 and 2008 respectively through political decree and decision. Political promises and fulfillments by the National Alliance of Rainbow Coalition (NARC) government in 2003 and Party of National Unity (PNU) in 2008 respectively are good examples. Politicians in democratic nations during elections period are sensitive and easily changed by the voters' opinion and demands. These politicians tend to please voters by increasing public expenditure in response to the demand of the low-income voters who through ballot demand equality in the country by voting politicians who are likely to respond to their demand which is in agreement with Fiscal Illusion Theory.

The paper makes the following two contributions. First, it empirically identifies some of the main common determinants affecting growth of public expenditure on education sector in Kenya through building on some well-established public policy, finance and economic theories. Just as seen from Model-1 and Model-2 representing general education sector and primary education subsector respectively were in agreement by large margin (see Table 1) with theories initial predictions of factors having a positive effect on growth of public expenditure on education. Second, the education policies have a big effect to financial 
theories' predictions and expectations and therefore, it will be easy for researchers to develop or modify the current theories to meet the ever changing national and global trends using the result of this study.

\subsection{Recommendation}

The public expenditure on education in Kenya as seen from the results still needs a lot of overhaul to enable the poor households to take their children to all levels of education. According to Imana (2017), the poor household have benefited greatly and partially from free primary and free secondary education respectively. This study therefore, recommends the following measures to be taken by the Kenyan government in order to improve the quality and bring equality to education sector. In addition, it will also reduce school drop-out rates, improve all levels of education transition rates and promote economic growth in the long run.

1. In order to make free primary and free day secondary education sustainable, the government should find reliable sources of revenue other than relying on traditional methods of funding such as grants and budget allocation which in most cases is not reliable.

2. The national government should devolve basic education (primary and secondary) to be managed by County governments since they are not only nearer to the people but also they are in the position to identify students from poor households easily. There is no doubt that the County Governments have done well in improving pre-primary level of education that was left to them to manage.

3. The policymakers and interested parties need to be reviewing and re-examining the values and purposes of basic education. They should be directing their efforts and capacities towards enhancing efficiency and effectiveness particularly in utilizing the scarce financial resources.

4. There is needs to review all syllabuses across entire levels of education so as to meet the current changing jobs demands and trends brought by current job market. A number of companies and organizations have reported saying that most students nowdays complete school while they are 'half-baked' which brings the question of quality and relevance of free education.

5. All education sector stakeholders need to be involved in all stages of education policies especially on cost and financing. The success of education policies in any particular country is based on good governance, efficient and a better establishment of financial management systems which is achievable through participation of all stakeholders. 


\section{References}

Abuya, B., Oketch, M., \& Musyoka, P. (2013). Why Do Pupils Dropout When Education is 'Free'? Explaining School Dropout Among the Urban Poor in Nairobi. Compare. A Journal of Comparative and International Education, 43(6), 740-762.

Allen, S. D., Sulock, J. M., \& Sabo, W. A. (1986). The Political Business Cycle: How Significant?. Public Finance Quarterly, 14(1), 107-112.

Al-Samarrai, S. (2003). Financing Primary Education for All: Public Expenditure and Education Outcomes in Africa. Inst. of Development Studies, University of Sussex.

Amutabi, M. N. (2003). Political Interference in the Running of Education in Post-independence Kenya: A critical Retrospection. International Journal of Educational Development, 23(2), 127-144.

Block, S. A. (2002). Political Business Cycles, Democratization, and Economic Reform: The Case of Africa. Journal of Development Economics, 67(1), 205-228.

Boslaugh, S. (2007). Secondary Data Sources for Public Health: A Practical Guide. Cambridge University Press.

Buchanan, J. M., \& Wagner, R. E. (1977). Democracy in deficit. Acad. Press.

Bwonda, E. N. (2013). Essays on Benefit Incidence and Efficiency of Public Spending on Education and Training in Kenya. (Doctoral dissertation, University of Nairobi).

Deolalikar, A. B. (1998). Increasing School Quantity Versus Quality in Kenya: Impact on Children from Low-and High-income Households. The Journal of Policy Reform, 2(3), 223-246.

Dye, T. (2005). Understanding Public Policy. 11th ed. New Jersey: Pearson Education.

Dye, T. (1978). Understanding Public Policy. 3rd ed. Eaglewood Cliffs, N. J.: Prentice-Hall

Etzioni, A. (1967). Mixed-Scanning: A 'Third' Approach to Decision-Making.

Fisher, G. W. (1964). Interstate Variation in State and Local Government Expenditure. National Tax Journal, 17(1), 57-74.

De Foville, A. (1907). La monnaie. J. Gabalda \& cie.

Friedman, M. (2010). Quantity Theory of Money. In Monetary Economics, pp. 299-338. Palgrave Macmillan UK.

Heckelman, J., \& Whaples, R. (1996). Political Business Cycles Before the Great Depression. Economics Letters, 51(2), 247-251.

Imana, D. K. (2017). Integrating the Culture of Constitutionalism in the Education Sector: Analysis of Public Education Spending, Reforms and Income Inequality in Kenya. International Journal of Humanities and Social Science, 7(5). Center for Promoting Ideas, 
USA.

Imana, D. K. (2016). The Socio-Political Context of Public Spending in Kenya: A Case of Education Inequality in Turkana County. International Journal of Educational Research and Information Science, 3(2). pp. 5-12

Jerono, C. R. (2009). Government Expenditure Components on Economic Growth in Kenya. International Journal of Business and Social Science, 4(4).

Keynes, J. M. (1936). The General Theory of Employment, Interest and Money, London; dt. Übers. von Fritz Waeger Allgemeine Theorie der Beschäftigung, des Zinses und des Geldes, Berlin und München, 10. Chicago.

Lindblom, C. E. (1959). The Science of "Muddling Through". Public Administration Review, 79-88.

Lindert, P. H. (2009). Growing Public: Social Spending and Economic Growth since the Twentieth Century. Vol. 2. New York: Cambridge University Press.

Lindert, P. H. (2004). Growing public: Volume 1, the story: Social spending and economic growth since the eighteenth century. Vol. 1. Cambridge University Press.

Levitt, M. S., \& Joyce, M. A. S. (1987). The Growth and Efficiency of Public Spending. Cambridge: The National Institute of Economic and Social Research. Occasional Papers XII, Cambridge University.

Malechwanzi, J. M., Shen, H., \& Mbeke, C. (2016). Policies of Access and Quality of Higher Education in China and Kenya. A comparative study. Cogent Education, 3(1), 1201990.

McGillvray, M., \& Morrissey, O. (2001). Aid Illusion and Public Sector Behaviour. Journal of Development Studies, 37(6), 118-136.

Mill, J. S. (1848). Principles of Political Economy with Some of Their Applications to Social Philosophy, by John Stuart Mill. JW Parker.

Mwiria, K. (2002). Vocationalization of Secondary Education: Kenya Case Study Prepared for Regional Vocational Skills Development Review. Human Development, Africa Region, World Bank.

Musgrave, R., \& Musgrave, P. (1989). Public Finance in Theory and Practice. 5th ed. Singapore: McGraw-Hill.

Mzonde, R. S. B. K. (2013). Antecedents and Income Distributive Effects of Public Expenditure on Education in Malawi.

Newcomb, S. (1885). Principles of Political Economy. Harper.

Ndonga, S. (2017). Ministry Disburses Sh22bn Free Education Funds. Capital News Article available on line at.

http://www.capitalfm.co.ke/news/2017/02/ministry-disburses-sh22bn-free-education-funds/ 


\section{Macrothink}

Journal of Public Administration and Governance

ISSN 2161-7104

2017, Vol. 7, No. 4

Oates, W. E. (1988). On the Nature and Measurement of Fiscal Illusion: A Survey, 1 in G. Brennan et al., eds., Taxation and Fiscal Federalism: Essays in Honour of Russel Mathews.

Ojiambo, P. O. (2009). Quality of Education and Its Role in National Development: A case study of Kenya's educational Reforms. Kenya Studies Review, 1(1), 133-149.

Potrafke, N. (2006). Parties matter in allocating expenditures: Evidence from Germany (No. 652). DIW Discussion Papers.

Puviani, A. (1903). Teoria dell'Illusione Finanziara [The Theory of Fiscal Illusion]. Milano/Palermo/Napoli: Remo Sandron, Editore-Libraio della R. Casa.

Rodrik, D. (1998). Why Do More Open Economies have Bigger Governments?. Journal of political Economy, 106(5), 997-1032.

Snyder, J., \& Yackovlev, I. (2000). Political and economic determinants of changes in government spending on social protection programs. Cambridge, United States: Massachusetts Institute of Technology. Mimeographed document.

Tanzi, V., \& Schuknecht, L. (2000). Public spending in the 20th century: A global perspective. Cambridge University Press.

Vartanian, T. P. (2010). Secondary data analysis. Oxford University Press.

Ventura, L. B. (2006). Trade openness and preferences for redistribution: a cross-national assessment of the compensation hypothesis. Business and Politics, 8(2), 1-50.

Wagner A. (1893). The Foundation of the Political Okonomie (3rdedn), Leipzig, Germany.

Wiseman, J., \& Veverka, J. (1961). The growth of public expenditure in the United Kingdom. Princeton University Press.

World Bank (WB). (2015). Kenya Rural population (\% of total population). World Urbanization prospects available online at:

http://data.worldbank.org/indicator/SP.RUR.TOTL.ZS?locations=KE

Yoon, J. (2009). Globalization and the welfare state in developing countries. Business and Politics, 11(2), 1705-1771. 


\section{APPENDIX A}

\section{Factors Affecting Growth of Public Expenditure (GE \& GP)}

Appendix A1: Education Sector Expenditure (GE)

\begin{tabular}{|c|c|c|c|c|c|c|c|}
\hline \multirow{2}{*}{$\begin{array}{c}\text { Independent } \\
\text { Variables }\end{array}$} & \multicolumn{2}{|c|}{$\begin{array}{c}\text { Unstandardized } \\
\text { Coefficients }\end{array}$} & \multirow{2}{*}{$\frac{\begin{array}{c}\text { Standardized } \\
\text { Coefficients }\end{array}}{\text { Beta }}$} & \multirow[t]{2}{*}{$\mathbf{T}$} & \multirow[t]{2}{*}{ Sig. } & \multicolumn{2}{|c|}{$\begin{array}{l}\text { Collinearity } \\
\text { Statistics }\end{array}$} \\
\hline & B & Std. Error & & & & Tolerance & VIF \\
\hline$($ Constant $)$ & -8.759 & 8.641 & & -1.014 & 0.322 & & \\
\hline INF & 0.062 & 0.069 & 0.167 & 0.899 & 0.378 & 0.243 & 4.119 \\
\hline PCG & 0.369 & 0.188 & 0.262 & 1.967 & $.062 *$ & 0.476 & 2.102 \\
\hline URB & 0.297 & 0.442 & 0.236 & 0.671 & 0.509 & 0.068 & 14.701 \\
\hline DEF & 0.135 & 0.058 & 0.379 & 2.312 & $.030 * *$ & 0.313 & 3.194 \\
\hline ITR & 0.027 & 0.049 & 0.214 & 0.558 & 0.582 & 0.057 & 17.54 \\
\hline GEt-1 & 0.376 & 0.099 & 0.486 & 3.812 & $.001 * * *$ & 0.517 & 1.933 \\
\hline PTEM & -0.169 & 0.097 & -0.331 & -1.743 & $.095 *$ & 0.233 & 4.292 \\
\hline STEM & 0.257 & 0.112 & 0.633 & 2.291 & $.032 * *$ & 0.11 & 9.076 \\
\hline DUEL & -1.492 & 0.691 & -0.225 & -2.159 & $.042 * *$ & 0.772 & 1.296 \\
\hline GLOB & 0.008 & 0.014 & 0.188 & 0.566 & 0.577 & 0.076 & 13.128 \\
\hline GRANT & -0.415 & 0.203 & -0.514 & -2.049 & $.053 *$ & 0.134 & 7.479 \\
\hline TGE & 1.24 & 0.413 & 0.644 & 3.001 & $.007 * *$ & 0.183 & 5.465 \\
\hline $\mathbf{R 2}=.815$ & \multicolumn{2}{|c|}{ Adjusted R2 $=.714$} & F - Change & 8.072 & \multicolumn{3}{|c|}{ Durbin-Wats on $=2.279$} \\
\hline
\end{tabular}

(a). Dependent Variable: Z Scores (GE), (b). All Predictors (IVs): Z Scores

Note: $*$ Significant at $10 \%$. ** Significant at $5 \%$. *** Significant at $1 \%$.

Appendix A2: Primary Education Expenditure (GP)

\begin{tabular}{|c|c|c|c|c|c|c|c|}
\hline \multirow{2}{*}{$\begin{array}{c}\text { Independent } \\
\text { variables }\end{array}$} & \multicolumn{2}{|c|}{$\begin{array}{c}\text { Unstandardized } \\
\text { Coefficients }\end{array}$} & \multirow{2}{*}{$\begin{array}{c}\begin{array}{c}\text { Standardized } \\
\text { Coefficients }\end{array} \\
\text { Beta }\end{array}$} & \multirow[t]{2}{*}{$\mathrm{T}$} & \multirow[t]{2}{*}{ Sig. } & \multicolumn{2}{|c|}{$\begin{array}{c}\text { Collinearity } \\
\text { Statistics }\end{array}$} \\
\hline & B & Std. Error & & & & Tolerance & VIF \\
\hline$($ Constant) & -0.079 & 5.231 & & -0.015 & 0.988 & & \\
\hline INF & 0.082 & 0.042 & 0.186 & 1.944 & $.064 *$ & 0.252 & 3.974 \\
\hline PCG & 0.11 & 0.115 & 0.066 & 0.953 & 0.351 & 0.481 & 2.08 \\
\hline URB & -1.258 & 0.243 & -0.847 & -5.179 & $.000 * * *$ & 0.086 & 11.661 \\
\hline DEF & -0.081 & 0.033 & -0.194 & -2.454 & $.022 * *$ & 0.366 & 2.729 \\
\hline ITR & -0.005 & 0.03 & -0.031 & -0.155 & 0.878 & 0.057 & 17.478 \\
\hline GEt-1 & 0.09 & 0.061 & 0.098 & 1.475 & 0.154 & 0.518 & 1.931 \\
\hline PTEM & 0.215 & 0.058 & 0.357 & 3.701 & $.001 * * *$ & 0.247 & 4.054 \\
\hline DUEL & 0.49 & 0.425 & 0.063 & 1.152 & 0.261 & 0.777 & 1.287 \\
\hline GLOB & -0.011 & 0.009 & -0.219 & -1.296 & 0.208 & 0.08 & 12.442 \\
\hline GRANT & 0.016 & 0.124 & 0.016 & 0.125 & 0.901 & 0.135 & 7.386 \\
\hline TGE & 0.484 & 0.238 & 0.212 & 2.038 & $.053 * *$ & 0.211 & 4.743 \\
\hline
\end{tabular}

R2 $=.947 \quad$ Adjusted R2 $=.922 \quad$ F - Change $=37.562 \quad$ Durbin-Wats on $=1.810$ (a). Dependent Variable: Z Scores (GP), $\quad$ (b). All Predictors (Ivs): Z Scores Note: * Significant at $10 \% . * *$ Significant at $5 \%$. *** Significant at $1 \%$. 


\section{APPENDIX B}

\section{Factors Affecting Growth of Public Expenditure (GS \& GU)}

Appendix B1: Secondary Education Expenditure (GS)

\begin{tabular}{|c|c|c|c|c|c|c|c|}
\hline \multirow{2}{*}{$\begin{array}{c}\text { Independent } \\
\text { Variables }\end{array}$} & \multicolumn{2}{|c|}{$\begin{array}{c}\text { Unstandardized } \\
\text { Coefficients }\end{array}$} & \multirow{2}{*}{$\begin{array}{c}\begin{array}{c}\text { Standardized } \\
\text { Coefficients }\end{array} \\
\text { Beta } \\
\end{array}$} & \multirow[t]{2}{*}{$\mathrm{T}$} & \multirow[t]{2}{*}{ Sig. } & \multicolumn{2}{|c|}{ Collinearity Statistics } \\
\hline & $\mathrm{B}$ & Std. Error & & & & Tolerance & VIF \\
\hline (Constant) & 4.298 & 1.531 & & 2.808 & 0.009 & & \\
\hline INF & 0.049 & 0.012 & 0.434 & 4.192. & $000 * * *$ & 0.68 & 1.471 \\
\hline DEF & -0.01 & 0.014 & -0.068 & -0.52 & 0.605 & 0.435 & 2.297 \\
\hline ITR & -0.01 & 0.009 & -0.184 & -0.75 & 0.462 & 0.12 & 8.336 \\
\hline GLOB & -0 & 0.004 & -0.225 & -0.75 & 0.461 & 0.081 & 12.396 \\
\hline GSEN & 0.001 & 0 & 0.34 & 1.546 & 0.134 & 0.151 & 6.627 \\
\hline DEBT & 0.001 & 0.006 & 0.01 & 0.089 & 0.93 & 0.594 & 1.682 \\
\hline MS & -0.11 & 0.049 & -0.522 & -2.26 & $.032 *$ & 0.137 & 7.273 \\
\hline AGRI & 0.061 & 0.051 & 0.173 & 1.2 & 0.241 & 0.349 & 2.867 \\
\hline $\mathbf{R} 2=.810$ & \multicolumn{2}{|c|}{ Adjusted R2 =.752 } & \multicolumn{3}{|c|}{$\mathbf{F}-$ Change $=13.881$} & Durbin-Wa & $=2.167$ \\
\hline
\end{tabular}

(a). Dependent Variable: Z Scores (GS), (b). All Predictors (Ivs): Z Scores

Note: * Significant at $10 \%$.** Significant at $5 \%$.*** Significant at $1 \%$.

Appendix B2: University Education Expenditure (GU)

\begin{tabular}{|c|c|c|c|c|c|c|c|}
\hline \multirow{2}{*}{$\begin{array}{l}\text { Independent } \\
\text { Variables }\end{array}$} & \multicolumn{2}{|c|}{$\begin{array}{c}\text { Unstandardized } \\
\text { Coefficients }\end{array}$} & \multirow{2}{*}{$\begin{array}{c}\begin{array}{r}\text { Standardized } \\
\text { Coefficients }\end{array} \\
\text { Beta }\end{array}$} & \multirow[t]{2}{*}{$\mathrm{T}$} & \multirow[t]{2}{*}{ Sig. } & \multicolumn{2}{|c|}{ Collinearity Statistics } \\
\hline & B & Std. Error & & & & Tolerance & VIF \\
\hline$($ Constant $)$ & 0.048 & 0.164 & & 0.29 & 0.774 & & \\
\hline PCG & 0.366 & 0.2 & 0.366 & 1.829 & $.079 *$ & 0.677 & 1.477 \\
\hline URB & -0.581 & 0.673 & -0.581 & -0.863 & 0.396 & 0.06 & 16.691 \\
\hline GUEN & 0.861 & 0.712 & 0.775 & 1.21 & 0.237 & 0.066 & 15.136 \\
\hline $\mathrm{GE}_{\mathrm{t}-1}$ & 0.452 & 0.286 & 0.408 & 1.583 & 0.126 & 0.408 & 2.453 \\
\hline DEBT & -0.286 & 0.229 & -0.286 & -1.248 & 0.223 & 0.518 & 1.932 \\
\hline GLOB & -0.345 & 0.322 & -0.345 & -1.073 & 0.293 & 0.262 & 3.823 \\
\hline GRANT & 0.63 & 0.388 & 0.508 & 1.624 & 0.116 & 0.277 & 3.614 \\
\hline DUEL & 0.141 & 0.17 & 0.141 & 0.831 & 0.414 & 0.941 & 1.063 \\
\hline
\end{tabular}

(a). Dependent Variable: Z Scores (GU), (b). All Predictors (Ivs): Z Scores

Note: $*$ Significant at $10 \%$. ** Significant at 5\%.*** Significant at $1 \%$.

\section{Copyright Disclaimer}

Copyright for this article is retained by the author(s), with first publication rights granted to the journal.

This is an open-access article distributed under the terms and conditions of the Creative Commons Attribution license (http://creativecommons.org/licenses/by/4.0/). 